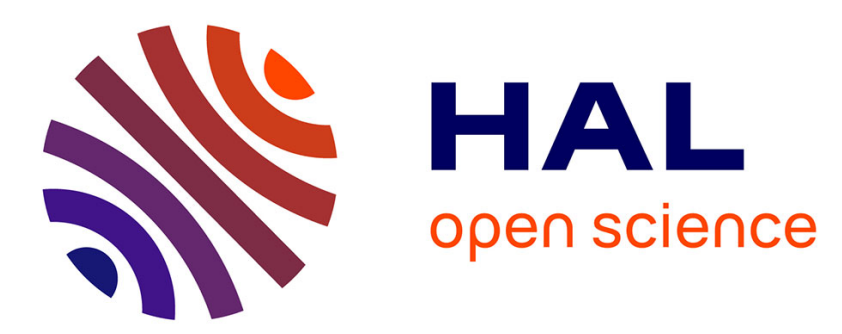

\title{
Producing expert capital: how opposing same-sex marriage experts dominate fields in the United States and France
}

\author{
Michael Stambolis-Ruhstorfer
}

\section{To cite this version:}

Michael Stambolis-Ruhstorfer. Producing expert capital: how opposing same-sex marriage experts dominate fields in the United States and France. Social Movement Studies, 2018, 19 (1), pp.38-62. 10.1080/14742837.2018.1482206 . hal-02123644

\section{HAL Id: hal-02123644 \\ https://hal.science/hal-02123644}

Submitted on 8 May 2019

HAL is a multi-disciplinary open access archive for the deposit and dissemination of scientific research documents, whether they are published or not. The documents may come from teaching and research institutions in France or abroad, or from public or private research centers.
L'archive ouverte pluridisciplinaire HAL, est destinée au dépôt et à la diffusion de documents scientifiques de niveau recherche, publiés ou non, émanant des établissements d'enseignement et de recherche français ou étrangers, des laboratoires publics ou privés. 


\title{
Social Movement Studies
}

\section{Producing Expert Capital: How Opposing Same- Sex Marriage Experts Dominate Fields in the United States and France}

Michael Stambolis-Ruhstorfer (Université Bordeaux Montaigne)

\begin{abstract}
:
This paper examines experts who have testified before U.S. and French courts and legislatures on same-sex marriage and parenting debates between 1990 and 2013. Experts can provide special evidentiary weight to political arguments, which I call expert capital. For this reason, social movements and decision-makers on both sides of the debate solicit them. Yet, because of specific national conditions, this article shows that not all experts have the same capacity to use their respective academic and professional resources to impact policymaking in each country. Drawing on 71 in-depth interviews and ethnographic observation in both the U.S. and France, it analyses how progressive and conservative experts have struggled for dominance in their fields. Results show that American progressive experts have achieved a degree of power in their fields as their conservative counterparts turn to resources outside the academic mainstream. In France, progressives have only recently begun to challenge conservatives' dominant position. I argue that these power balances, which are subject to change, are due to: 1 ) size and centralization of knowledge regimes; 2 ) disciplinary and university reactions to research on gender and sexuality; 3 ) academic and professional organization strength; 4) social acceptance of gay families; and, 5) the degree of division among allied experts. These findings have implications for research on social movements. They show that the capacity of experts to provide expert capital to their activist and decision-maker allies is constrained and enabled by factors specific to knowledge production fields that vary cross-nationally.
\end{abstract}

\section{Keywords:}

experts; expert capital; social movements; same-sex marriage; United States; France

\section{Correspondence Address:}

Michael Stambolis-Ruhstorfer

UFR Langues et Civilisations

Université Bordeaux Montaigne

19 esplanade des Antilles

33607 Pessac, France

michael.stambolis@u-bordeaux-montaigne.fr 


\section{Notes on Contributors}

Michael Stambolis-Ruhstorfer is a sociologist of law, knowledge, culture, gender, and sexuality. He is an assistant professor (maître de conférences) in American studies at the Université Bordeaux Montaigne.

\section{Author Links}

Author 1 ORCID ID: https://orcid.org/0000-0002-7890-1816

Author 1 Social Media Profiles: https://www.linkedin.com/in/michael-stambolis-ruhstorfer$7186596 b /$

\section{Acknowledgements:}

This research was supported by funding from the National Science Foundation (grant SES 1226663), the Bourse Chateaubriand of the Ministère des affaires étrangères de France and the Fulbright Commission, the UCLA Center for European and Eurasian Studies, and the UCLA Graduate Division's Dissertation Year Fellowship program. My sincere thanks goes to the interviewees for sharing their experiences, to the reviewers and editors at Social Movement Studies for their constructive criticism, and to the members of my dissertation committee, chaired by Abigail Saguy, for their guidance.

In 2013-14, U.S. federal judges heard the cases Hollingsworth v. Perry (2013) and DeBoer v. Snyder (2014), to determine the constitutionality of bans against same-sex marriage and adoption. ${ }^{1}$ During the trials, litigators on both sides called expert witnessesincluding historians, psychologists, and sociologists - to argue that the science about, for example, outcomes of children raised by same-sex couples supported their stance. Of twenty academic experts, fourteen testified in favor of marriage while only six testified against. The judges thus faced overwhelmingly favorable scientific evidence that likely contributed to the proponents' ultimate success, culminating in the Supreme Court's Obergefell v. Hodges (2015) decision striking down same-sex marriage bans nationwide. ${ }^{2}$ American attorneys fighting against gay family rights found few accredited academics and professionals willing to testify. The science, or at least the scientific establishment, appeared not to support them.

At almost the same time, lawmakers in France's Parliament were considering legalizing same-sex marriage and adoption. For months before the vote, which ultimately

\footnotetext{
${ }^{1}$ Hollingsworth v. Perry, 133 S. Ct. 2652 (2013); DeBoer v. Snyder, 973 F. Supp. 2d 757, 775 (E.D. Mich. 2014).

2 Obergefell v. Hodges, 135 S. Ct. 1039 (2015)
} 
passed in May 2013, the Judiciary Committee held hundreds of hours of live streamed hearings featuring experts whose testimony made the nightly news and talk shows. The social scientists, psychoanalysts, and jurists testifying were almost evenly split ideologically with some variation by discipline. Jurists and mental health professionals, for example, were less supportive of the bill than sociologists. Thus, relative to American judges, French lawmakers faced expert discourse less clearly favorable to their reform. Moreover, conservative experts gave a scientific veneer to anti-gay family backlash that caused in part the Socialist majority to abandon plans to legalize assisted reproduction technologies (ART) for lesbian couples.

These examples illustrate the particular role of experts in shaping human rights law. While much scholarship acknowledges that academics and professionals impact policymaking on technical issues (Fischer, 2000), such as global warming (Dilling \& Lemos, 2011), experts are also central to so-called morality politics (Mucciaroni, 2008). They give evidentiary weight for or against arguments — such as same-sex marriage opponents who say children need a mother and father-that decision-makers use as justifications. Furthermore, because of this symbolic power, which I call "expert capital," social movements target experts in order to legitimize their positions (Armstrong \& Bernstein, 2008). Yet, the availability of expertise and its ideological balance, as the above examples demonstrate, seem to depend on national context. Indeed, despite dealing with the same legal questions, decision-makers in each country faced different expert pools. That American litigators-but not French lawmakers - had more testimony in favor of gay families suggests differences in knowledge production fields.

Given these differences in the ideological orientation of experts testifying in the United States and France on gay family law, I ask: 1) What power do experts supporting and opposing same-sex marriage and parenting have in their national knowledge production fields? 2) How has that power changed over time, if at all? And, 3) What explains their 
current positions? Answers to these questions shed light on nationally specific barriers and opportunities knowledge producers face when doing their work. Understanding this should make clear that experts' capacity to speak from a position of power on major reforms is contingent on context. People analyzing or mobilizing expert capital, including decisionmakers and social movements, may benefit from knowing how experts they solicit navigate their knowledge production fields.

\section{Expert Capital and Gay Family Rights}

International variation in gay family rights - defined as laws recognizing same-sex couples (i.e. marriage and civil-unions) and their parent-child relationships (i.e. access to ART, surrogacy, and adoption) — is in part due to the ways in which people pushing for and against change interact with nationally specific political and legal institutions, cultural frameworks, and each other (Bernstein \& Naples, 2015; Hull, 2006; Mucciaroni, 2008; Paternotte, 2011; Smith, 2008). Experts-people decision-makers call upon usually because of their scientific or professional qualifications (Eyal \& Buchholz, 2010) — play a key role in advancing or hindering these rights (Becker, 2015; Borrillo \& Fassin, 2001; Richman, 2009; Yoshino, 2015). Indeed, everyone staking a claim in these debates makes arguments in order to justify themselves (Boltanski \& Thévenot, 1991). To gain credibility, people try to deploy knowledge they believe will be convincing in their national institutional context (Ferree, 2003), which is why they sometimes turn to experts, who are the focus of this article.

Expertise, especially when grounded in peer-reviewed science and backed by recognized disciplinary or professional organizations, can be persuasive in these debates. For example, a variety of social science, such as that focusing on the demographics of same-sex couples, their parenting, the outcomes of their children, and the social effects of legalizing same-sex marriage, appear central in debates globally (Adams \& Light, 2015; Badgett, 2009; 
Borrillo \& Fassin, 2001; Bottoms, Kovera, \& McAuliff, 2002; Mezey, 2009). Both supporters and opponents (Fetner, 2008; Kuhar, 2015) of gay family rights claim the science supports them. These advocates thus behave like those in other social movements, such as climate change activism (Dilling \& Lemos, 2011; Dunlap \& Jacques, 2013), who engage expertise as part of their strategy toolkit (Armstrong \& Bernstein, 2008).

In this way, expertise functions as what I-inspired by Murphy et al. (2007)—call “expert capital.” Activists and decision-makers mobilize experts' knowledge, making expert capital a form of objectified cultural capital (Bourdieu, 1986). Yet, because only experts can produce it, expert capital depends on experts' perceived legitimacy, credentials, and access to resources in their fields. That also makes it embodied within experts themselves. Although activists can forge alliances with experts that share their ideological perspectives (Gregorio, 2014; Meyer, 2004), sometimes through mediating groups like think tanks (Medvetz, 2012), academics and professionals form their own "epistemic communities" (Knorr-Cetina, 1999) within knowledge production fields that overlap with but are distinct from political fields (Fligstein \& McAdam, 2012; King \& Walker, 2014). Furthermore, though some activists can become experts themselves (Cresswell \& Spandler, 2013; Epstein, 1996), doing so requires that they operate within the norms of knowledge production fields. Because of this relative autonomy, to complement research on social movements, I investigate the fields in which experts work to understand how they gain expert capital for policy purposes.

Like political (Swartz, 2013) and scientific fields (Bourdieu, 1975), I conceptualize the gay family knowledge production field as competitive and hierarchical. Within it, access to power, such as symbolic and materials resources including funding, disciplinary recognition, or professional promotion are unevenly distributed. Like other knowledge production fields on contentious subjects (Dilling \& Lemos, 2011), political ideologies organize these hierarchies. When experts of a particular stance dominate their field, they 
produce more research and prestige, increasing the value of their expert capital relative to their ideological rivals, whose power is reduced (Eyal \& Buchholz, 2010). These dynamics, therefore, have repercussions on those who use expert capital. Furthermore, similar to the political mobilizations with which they interact, knowledge production fields vary across national contexts (Jasanoff, 2004) and are therefore best understood comparatively.

\section{Comparing American and French Knowledge Regimes}

Drawing on comparative political science (Doherty \& Hayes, 2014; Tarrow, 2010) showing the merits of focused international comparison for revealing mechanisms of social phenomena, I compare gay family knowledge production fields in the U.S. and France. These countries share characteristics that form a baseline for comparison (Lamont \& Thévenot, 2000). They are both rich industrialized countries whose democracies formed after revolutions in the same era based on the Enlightenment principles of freedom and equality. Yet, they also diverge in key ways that may reveal factors affecting gay family experts as they strive for power in their national fields.

First, they diverge in their political approaches to inequality and difference (Lamont, 2002). American policies tend to recognize and count people according to social characteristics based on the idea that overcoming discrimination requires acknowledging differences. In contrast, French traditions of republican universalism, discourage the acknowledgement of race, religion, and sexuality (Brubaker, 1992; Gunn, 2004; McCaffrey, 2005) because doing so would, from this perspective, engender discrimination. As a result, French academics researching racial minorities, for example, are restricted in their capacity to study people of color relative to Americans (Simon, 2008). Experts studying gay families may face similar limitations.

Second, they differ in political and legal systems. The U.S. has a federal, common law system, with significant legal variation across states. This decentralized, court-centered 
approach allowed early legalization of some gay family rights in some states (Mezey, 2009).

France's centralized, civil law, legal system has prevented any recognition of gay families until the legislature passed the Pacs in 1999 - a law recognizing same and different-sex civil unions but not gay parenting - and marriage and adoption in 2013. Differences in legal recognition could also impact the capacity of people studying these groups in each country.

Third, the U.S. and France differ in their "knowledge regimes" (Campbell \& Pedersen, 2014) that organize the production, dissemination, and purpose of expertise (Fourcade, 2009). In the U.S., with a large and decentralized knowledge regime, "structural fragmentation"- the federal system with many outlets for reform and separation of power between government branches-decreases the relative importance of state-sponsored experts relative to Europe (Brint, 1996, p. 134). Indeed, activist and professional organizations as well as think tanks on both sides of gay rights, especially those involved in "cause lawyering" (Cimmings \& NeJaime, 2009), developed strong ties to researchers and academics. These factors contribute to the on-going development of research on sexual minority issues both within American universities as well as professional and academic organizations.

In contrast, the smaller, more centralized French knowledge regime favors bureaucracies where technocrats and elite intellectual experts exert direct influence on the policy process. France, is a representative case of a technocracy where state institutions, generally in Paris, produce most influential knowledge (Brint, 1996, pp. 192-193). For example, opponents of gay family rights found strong allies in the corps of high-ranking officials of the states' social services (Commaille, 2006). Further, French think tanks are relatively small and new. They are less able to counter state-produced knowledge or act as mediators between elite experts and decision-makers, as they do in the U.S. (Bérard \& Crespin, 2010). How progressive and conservative gay family experts navigate the barriers 
and resources created by these knowledge regimes - and the effects they have on their relative power in their national fields - is the focus of this article.

\section{Data and Methods}

To understand how American and French experts contributing to gay family policy debates work, I conducted 72 in-depth interviews (35 in the U.S. and 37 in France) with people who testified before U.S. and French courts and legislatures between 1990 and 2013. I also interviewed key lawmakers and lawyers who organized bills and litigation on these issues. Tables 1 and 2 provide the list of interviewees organized by public stance on same-sex marriage (56 were in favor and 15 against at the time of the interviews).

\section{[INSERT TABLES 1 AND 2 HERE]}

I complemented these interviews, conducted in 2013-2014, with ethnographic observation at events organized by universities, professional organizations, think tanks, and activist groups featuring experts focusing on gay families. Table 3 lists events I attended. At these events I informally interviewed over 100 participants inquiring about their work and involvement in policymaking. Finally, I gained insider perspective on family sociologists, a subset of these experts. In the U.S., I co-authored a review of the literature (Moore \& Stambolis-Ruhstorfer, 2013), which led to many informal conversations with American family sociologists. In France, I joined an interdisciplinary team in 2014 conducting the first cohort study of children raised by same-sex couples.

\section{[INSERT TABLE 3 HERE]}

To select interviewees, I analyzed archives of same-sex marriage and parenting reforms from 1990 to 2014 to identify which people provided and/or organized testimony in each country (Stambolis-Ruhstorfer, 2015) and contacted them directly. I sought to speak with people from multiple disciplines and think tanks and who had been involved in the 
debates on either side of the issue for different lengths of time.

The final sample reflects the variety of categories of experts, including professionals and academics, as well as people straddling research and activism, such as think tank and organization leaders, who participated in policy debates. It does not, however, completely capture the scope of views in any given discipline or field; I only formally interviewed people participating in decision-making arenas, which limits my capacity to discus the experiences of professionals not taking part in policymaking.

The sample is also unbalanced in terms of interviewee ideological orientations. Although strict parity between interviewees would not accurately reflect the current fieldresearch suggests more experts testifying in support of gay families in recent U.S. court cases and more against in French legislatures (Stambolis-Ruhstorfer, 2015; Yoshino, 2015)—my sample over represents supportive experts.

Despite considerable effort to reach them, limited representation of conservative experts may reflect an assumption about my politics as an American sociologist having published on sexuality and a resultant suspicion of my motives. Because professional reputations are crucial for establishing expert credibility in certain contexts, such as courts, giving an interview has high stakes, which explains their caution. It may also explain why Maggie Gallagher and Jennifer Morse, who left the academy but provided expertise in briefs and legislatures, agreed to interviews. Perhaps they felt they had less to lose.

Many interview solicitations to conservatives went unacknowledged and unanswered. Four acknowledged my request but declined an interview and two-Americans Mark Regnerus, a sociologist, and Robert George, a professor of jurisprudence-agreed to an interview but stopped responding during scheduling. One retracted after the interview expressing concern about their reputation. Among progressives I solicited, four declined to participate. Two interviewees, one on each side, requested to review full interview transcripts 
or approve direct quotes in published work. These recruiting circumstances reveal the level of political polarization and tension among experts, which I analyze below. Note, although I refer to "progressive" and "conservative" experts, these labels only relate to their stances relative to support (progressive) or opposition (conservative) to gay family rights. Interviewees did not necessarily use these labels themselves.

I conducted interviews in person, over the telephone, and via videoconference. I asked about their work (motives, support systems, experiences in their respective domains, etc.), their involvement in providing or organizing expert testimony, and their views on gay families debates. I had the interviews fully transcribed and used HyperResaerch to code and analyze them thematically along with the ethnographic fieldnotes.

\section{Power struggles in knowledge production fields in the 2010s}

In the U.S. and France of the 2010s, experts face nationally specific fields where balances of power between gay family rights opponents and supporters differ. While American expert supporters are more dominant relative to opponents within mainstream universities and professional organizations, in France they are more marginalized and have less power relative to conservatives. These configurations, reflecting the status quo at the time of data collection, are not static; they have changed over time and are likely to evolve as the factors that cause them, which I discuss in the next section, shift.

Relative to France, over the last 30 years in the U.S., work on sexual minorities, same-sex couples, and their children has become an established part of academic and professional research agendas. Among the experts I interviewed, this newfound recognition within their disciplines was acquired slowly and after resistance in the 1970s and 1980s, including difficulty publishing, securing funding, and getting jobs. For example, William Eskridge, a pioneer of LGBT law as a subfield, was denied tenure in the 1980s in part 
because he was gay. Similarly, Gregory Herek's research (Maher et al., 2009) on the psychology of anti-gay attitudes was "not a very respected area of study" in the early 1980s. Resistance, however, became less frequent by the 1990s, interviewees said. By then, many were receiving funding from major organizations, such as Herek from the National Institute of Mental Health (NIMH), and publishing in major journals.

The growing American mainstreaming of research on sexuality and gender has benefited progressives. Today, progressive American interviewees described a field where their work is lauded, often funded, and usually supported by most of their universities. Their descriptions echo research (Cardiff \& Klein, 2005; Klein \& Stern, 2005) suggesting support for progressive stances in the American academy especially among social scientists in nonreligiously affiliated institutions. Almost all progressive interviewees also said their work is currently welcomed by their respective organizations, such as the American Sociological Association (ASA), the American Psychological Association (APA), the American Psychiatric Association, and the American Bar Association (ABA). Some of these organizations have welcomed working groups devoted to gay family research for several decades, though sometimes after contentious debates and dissention.

Progressive American interviewees have also reached prestigious positions within their universities and organizations. For example, Eskridge, is now a professor at Yale, currently the highest ranked law school in the country. They also pointed to the multiplication of gender studies programs in American universities and faculty members specializing in gender, sexuality, and gay families as proof of their professional mainstreaming. Many have received top prizes in their fields, such as Charlotte Patterson, one of the first psychologists to study same-sex parenting, who was awarded the APA's 2009 Award for Distinguished Contributions to Research in Public Policy. Similarly, Patterson and Gary Gates - a demographer formerly at the William's Institute, UCLA's sexual orientation 
law think tank-have joined committees at the U.S. Census Bureau, one of the most crucial sources of data on the U.S. population. These distinctions reflect the growth of their power in U.S field over time.

As the topic of gay families has become more respected, interviewees espousing public positions against gay family rights are more marginalized. Their support for "traditional" family views and opposition to the funding, publication, and praise for gay family research have lost a platform for action within mainstream American universities and professional organizations. Indeed, as major groups take organizational-wide stances in favor of same-sex marriage and parenting, conservatives working in corresponding disciplines are by definition outside those institutional stances.

They said they felt increasing resistance to their work and stances. Academics, such as Brigham Young University law professor Lynn Wardle, and conservative think tank founders, such as activist Maggie Gallagher and former George Mason University professor Jennifer Roback Morse, who both have ties to scientists and lawyers involved in conservative politics, said those sharing their stances were more marginalized in mainstream fields. Some described personally experiencing or hearing about allies facing challenges from colleagues over tenure-particularly sociologists Bradford Wilcox and Mark Regnerus who work in mainstream universities - as well denunciations of their research in trade publications. Some said progressive scholars refused collaboration. For example, Douglas Allen, an economist at Simon Fraser University, claimed to have contacted sociologists, including Michael Rosenfeld, whose work $(2013 ; 2010)$ he and colleagues critiqued (2013) to ask for their data and feedback "and over all the years not a single one has ever replied [his emphasis]." Some progressives share the perception that conservative stances are currently more marginalized. Eskridge, for example, explained that among law scholars, "Almost nobody...will sit up and say I think gay people ought to be excluded from marriage. Some might believe it and would 
vote that way in private, but almost no one will say that in print or publically."

Despite their sense of marginalization, U.S. conservatives have developed alternative parallel structures to traditional academic institutions. Conservative or religiously affiliated groups have created their own large and well-funded universities, such as Liberty University in Virginia and Brigham Young University in Utah. These universities have been an institutional home for some of the conservative interviewees. Moreover, they have also founded American and international alternative professional, advocacy, and funding organizations. Examples include the American College of Pediatrics, the International Society of Family Law, and the Witherspoon Institute, which funded Regnerus's study (2012) on childhood outcomes that advocates unsuccessfully wielded in U.S. courts to argue against same-sex marriage. These venues allow them to collaborate but do not provide the same professional and scientific recognition as mainstream spaces even as they offer organizational resources.

In France, the balance of power between progressive and conservative experts is flipped. Although the situation has slowly begun to change, in general, relative to the U.S., experts working on gay families still experience significant professional marginalization. This situation is especially limiting for progressive interviewees. As recently as the 2000 s, sociologists, such as Martine Gross, and anthropologists, including Anne Cadoret, had significant difficulty securing any funding for research on gay families. They described senior colleagues publically greeting their work on same-sex couples and their children with "violent" hostility. For example, during a seminar at the Collège de France, in the early 2000s, one of Cadoret's colleagues shouted at her to "stop talking" because the colleague “could not stand what [she] was saying."

Only in the last decade have some recent graduates secured permanent positions. Senior colleagues of younger progressive scholars, including child psychiatrist, Stéphane 
Naudaud, anthropologist Jérôme Courduriès, and sociologist Virginie Descoutures all explicitly discouraged them from working on these topics. One jurist interviewee, who currently studies surrogacy law and did not want to be named on this issue, said her former dissertation advisor recently told her she now works on "perverted subjects." When Nadaud-whose supervisor was "a proponent of Anglo-American psychiatric [norms]"published his 2001 dissertation on the outcomes of children raised by same-sex couples, leaders in his field, such as conservative psychoanalyst Caroline Eliacheff (2001) decried his findings in national newspapers as naïve, unreliable, and partisan (Garnier, 2012).

In terms of prestige, it has been rare for these experts to receive recognition from French institutions. Some notable exceptions began in the wake of the 2013 legalization of same-sex marriage and adoption when President François Hollande awarded the Ordre de Mérite to Gross in 2014 and to gay family lawyer Caroline Mécary in 2013. He gave the Légion d'honneur in 2013 to the sociologist Irène Théry, who, as I analyze in the next section, switched from opposing to supporting gay family rights in the mid-2000s. Nevertheless, these recent accolades notwithstanding, progressive academics have had less peer recognition than their American progressives.

Conservative French experts have long held central positions within their fields. They continue to dominate the most important venues organizing French knowledge production, including top universities, public research institutes, prestigious Parisian hospitals, governmental commissions, and powerful public service advisory boards allocating state funding. Contrary to the American field, this is especially true "among jurists, [where] there are lots of people on the right," Françoise Dekeuwer-Défossez, a family law professor opposed to same-sex marriage, argued. Claire Neirinck is an illustrative example. Unlike her conservative U.S. colleagues, she has not suffered professionally because of involvement in anti-gay family mobilizing. She is a distinguished family law professor at the Université de 
Toulouse, a member of the editorial board of the flagship journal in her specialty, Droit de la Famille, and author of the adoption sections in the civil law edition of JurisClasseur, the reference manual for legal professionals. Emphasizing conservative strength, interviewees on both sides cited an open letter written by 170 jurists to the Sénat in protest against the 2013 marriage bill (AFP, 2013). Because "very well-known law professors at the grandes universities" signed the letter, progressive law scholars, such as Laurence Brunet, said they felt isolated. This dominant position has not gone uncriticized. For example, several progressive French law scholars rebutted the jurist's open letter online (Millard, Brunet, Hennette-Vauchez, \& Champeil-Desplats, 2013). Moreover, Neirinck and DekeuwerDefossez both suggested their junior colleagues behind the letter campaign may have created professional trouble for themselves in the long term by opposing same-sex marriage.

Among French mental health professionals, conservative psychiatrists and psychoanalysts have long spearheaded their professions' resistance to gay family rights (Borrillo \& Fassin, 2001; Robcis, 2013) and psychologists hold comparatively conservative attitudes toward gay families (Vecho \& Schneider, 2015). They say their dominance is fading. For example, Christian Flavigny, a psychiatrist at a major Parisian hospital and member of advisory boards on adoption policy, said his peers privately supported his stances but "let him go to the fire" alone before media and lawmakers. One of his well-connected conservative colleagues, Pierre-Lévy Soussan, agreed that conservative psychoanalysts are losing legitimacy because of progressive attacks. Elisabeth Roudinesco, a famous historian of psychoanalysis popular in the media has, in her words, made "permanent enemies in the psychoanalytic milieu," because she has denounced experts using psychoanalysis to argue against gay parenting.

These reactions suggest a potential wane in conservative dominance in France, which may accelerate as public support for and legal recognition of gay families increases. 
Furthermore, contrary to Americans, French conservatives lack alternative knowledge production organizations they can mobilize as they lose ground to progressives in official state agencies and organizations that make up the French knowledge production field. Recent events, however, may slow this decline. For example, Valérie Pécresse, the president of the Paris region who ran on an anti-gay family platform-eliminated her region's funding for research on gender and sexuality, which was one of the few French granting sources (Daumas, 2016). Thus, despite recent slippage, French conservative experts continued to wield more power in fields than progressives. We now turn our attention to the factors that led to these power distributions.

\section{Achieving field strength: national factors constraining and enabling experts}

The relative strength, in the 2010 s, of progressive gay family experts in the U.S. and conservative experts in France is the result of nationally specific resources and obstacles they faced in each country. The data indicate five interrelated but analytically distinct types: 1) size and centralization of knowledge regimes; 2) disciplinary and university reactions to research on gender and sexuality; 3) academic and professional organization strength; 4) social acceptance of gay families; and, 5) the degree of division among allied experts. In what follows, I describe how interviewees confronted these factors to arrive at their current circumstances.

\section{Size and centralization of knowledge regimes}

The size and centralization knowledge regimes in the U.S. and France have benefitted or hindered different experts. The large, decentralized, and less state-centered American system has advantaged progressives and conservative alike. In a large field with more opportunities than France, American progressives gained traction in some regions and grew 
their footholds over time while conservatives found homes in alternative organizations. In contrast, in France, the centralized, hierarchical, and state-centered system of universities has limited progressives. Because conservatives continue to occupy high-ranking seats in university policy boards and state-run commissions, almost all of which are in Paris, progressives have had, until recently, fewer opportunities within a smaller academic job market relative to Americans.

Americans on both sides described working in institutions across the country, sometimes when attracted with funding, promotions, or more acceptance. Eskridge, for example, moved to Georgetown University from the University of Virginia where he found support for his work on LGBT law. On the other side, Morse moved from George Mason University to the Hoover Institution, a conservative think tank at Stanford University, before leaving the academy and founding her own advocacy organization. The number and variety of higher education and research institutions gives American experts more possibilities than their French counterparts for developing careers and cultivating spaces that fit their agendas.

French interviewees have not had such flexibility because universities are less numerous, less independent, and more homogenous there. Key steps in academic hiring and promotions, for example, are nationally centralized. Many progressive interviewees, including law professor Daniel Borrillo and sociologist Eric Fassin, claimed their careers were stifled for decades because well-placed conservatives prevented their promotions. They had few options for overcoming these barriers.

Furthermore, most French non-university knowledge production organizations are linked to the state. Conservative experts have held key positions within commissions acting as official governmental advisors, which, in the words of one progressive expert, means, "People who are against a certain social evolution are in strategic positions." For instance, the state nominated Lévy-Soussan to the Agence de la biomédecine, the state administrative 
board responsible for regulating ART. Similarly, Xavier Lacroix, a philosophy professor and theologian, was appointed in 2008 to the Comité consultatif national d'éthique pour les sciences de la vie et de la santé (CCNE), a legally-mandated advisory board authoring nonbinding declarations on all bioethics legislation that has opposed ART for lesbians until 2017. Finally, the Union nationale des associations familiales (UNAF), a powerful state-mandated family association federation the government is required to consult when drafting policy, over represents conservative family groups. It has worked with conservative law professors, such as Claire Neirinck, to draft official stances on gay family rights (UNAF, 2012). Within this system, progressive experts have only begun advancing as conservatives retire or end their terms.

\section{Disciplinary and university reactions to research on gender and sexuality}

Disciplines and universities in each country have historically reacted to gender and sexuality research in ways that have aided American progressives but limited their French colleagues. Mirroring national differences in size and centralization, interviewees experienced the American system as more accommodating to path-breaking research on gay people and their families. Illustrating this, Patterson, one of the first U.S. psychologists to study children raised by same-sex couples, described institutional support for her novel work. For example, during a 1989 sabbatical at UC Berkeley her peers in the psychology department and the Beatrice Bain Research Group, a feminist studies community, encouraged her to publish the first review of the extant literature on the outcomes of children (Patterson, 1992). Patterson's experience was not uncommon among U.S. interviewees who were the first in their fields to work on these issues. While all said they experienced skepticism, especially in previous decades, they ultimately found support for their unusual work.

Relative to their French peers, this support allowed them to conduct significant 
empirical research on gay families creating the "scientific consensus" (Adams \& Light, 2015) that children raised by same-sex and different-sex couples fair equally well, which proved central for progressives in trials. Respondents having testified before U.S. courts on this consensus, including Gates and Rosenfeld, described how hard-won acceptance of such research in American social sciences multiplied studies with increasingly better data. Both pointed to some open-mindedness from journals, grant providers, review boards, and data collectors. Had U.S. disciplines rejected this research, scholarship on gay families would likely have stagnated, falling short of the perceived critical mass that has buttressed the progressive legal case and given progressive scholars strength in their fields. Indeed, the French case suggests as much.

French experts researching sexual minorities have faced chronic skepticism from their peers and institutions. Each had stories of resistance from colleagues and mentors. Like their American peers, they conducted research on marginal topics but did so in a markedly more hostile environment that remained resistant to their ideas and methodology for longer (Perreau, 2016). Contrary to the U.S., French universities did not develop minority studies programs in the wake of post-1960s social movements. Thus, few French universities have opened women and gender studies programs, which could have helped progressive experts. Furthermore, French disciplines have continued to disregard such topics. For example, unlike some U.S. law school curricula, according to Dekeuwer-Defossez, "It's unimaginable in France to open a course on LGBT oriented law." Similarly, decrying the conservativeness of the French academy, renowned anthropologist Maurice Godelier explained that "in the U.S. ... you have a veritable [literature on] "gay kinship, lesbian kinship."' Illustrating this erasure, several cited the omission of gay families from François de Singly's authoritative Sociologie de la Famille Contemporaine until the $3^{\text {rd }}$ edition (2007), despite his supervision of Descoutures's dissertation on lesbian mothers and awareness of gay family organizations. 
Refusals to grant academic recognition to sexual minorities in general, and gay families in particular, are consistent with French republican universalism's downplaying of social differences.

As a result of these circumstances, French scholars have had fewer opportunities and produced less research on gay families than peers in other countries (Vecho \& Schneider, 2005). French conservative experts have historically benefitted from this environment because academic and professional resistance to gay parenting research aligns with their ideological stances.

\section{Academic and professional organization strength}

The strength of academic and professional organizations in the U.S. and their relative weakness in France has also shaped power distribution. Organizational strength has been beneficial to Americans on both sides, but especially for progressives. They have used official academic and professional organizations to further the acceptance of gay family research while also pushing their professions to advocate on behalf of gay rights. Working within their decision-making frameworks, they built a collective structure for both producing and mobilizing their research. There are many examples in the data but the APA and ASA are particularly illustrative.

The APA has an established unit devoted to sexual minority issues: the Lesbian, Gay, Bisexual and Transgender Concerns Office. Its associate executive director, Clinton Anderson, described how the APA used this office and its in-house legal team to issue public policy statements and amicus curiae briefs supporting many gay right issues, including samesex marriage and gay parenting (American Psychological Association, 2005). To create these documents, Anderson has cultivated psychological experts, including Patterson, Herek, and Anne Peplau, for decades. 
The ASA has also intervened in gay family debates. For example, in 2013, ASA's Executive Council decided to respond to demands from ASA members that the organization take an official stance rejecting Regnerus's claim in Social Science Research (2012) that children fair poorly when raised by same-sex couples. This stemmed in part from a campaign Gates, Patterson, and other social scientists organized leading the journal to investigate the review and editorial process behind the article's publication. Agreeing that his stance mischaracterized the sociological research, the Council funded Wendy Manning, a family sociologists who, unlike other equally qualified colleagues, had not taken a public stance on Regnerus's article, to review the literature. Manning's review (2014), which was ultimately published, found no evidence of harm to children, debunking Regnurs's claims. It also formed the basis of an amicus brief ASA filed in support of same-sex marriage. ${ }^{3}$

As official organizations have taken increasingly progressive policy stances, American conservatives have used their own organizational power. They leverage a network of think tanks, advocacy organizations, and alternative professional groups from the Heritage Foundation and the Family Research Council to the Witherspoon Institute and the Marriage Law Foundation. Yet, despite the significant budgets of some, they do not carry the symbolic weight of official organizations that speak in the name of entire disciplines or professions. That credibility can be important in litigation where the standards of evidence require each side to substantiate their claim that science supports their case (Yoshino, 2015). U.S. progressive interviewees were also involved in their own think tanks, such as Lamda Legal and the William's Institute, which produces peer-reviewed social science for progressive gay rights causes. But, unlike conservatives, they also had official disciplinary organizations to undergird their stances.

Relative to their American counterparts, many French professional groups, such as

\footnotetext{
${ }^{3}$ Brief of The American Sociological Association as Amicus Curiae in Support of Perry and Windsor, Hollingsworth v. Perry and Windsor v. Bipartisan Legal Advisory Board, 570 U.S. 12-144 (2013).
} 
the Association Française de Sociologie and the Société Française de Psychologie, are small, low-budget, lack professional staffs, and have not produced significant contributions of any stance on gay family policy. Furthermore, consistent with other research (Béland \& Cox, 2010), the few respondents involved in think tanks, such as Théry and Geneviève Delaisi de Parseval at Terra Nova, said they have less impact than state-run advisory boards. French progressive experts thus could not leverage significant organizational resources to influence their fields like Americans. As a result, their capacity to collectively create progressive momentum in the disciplines that could impact policymaking and counter on-going conservative dominance has been limited. Absent strong professional organizations receptive of their work, French progressives' best option is to increase their representation in state advisory commissions where conservatives have dominated until recently. Yet, because appointment to such positions is both political-elected officials are responsible for nominating some members - and collegial, this long-term strategy is contingent, in part, on elections.

\section{Social acceptance of gay families}

Social acceptance — or not—of same-sex couples raising children, as measured by their legal recognition, visibility in the media, and representation in organizations affects the capacity of experts studying them to gain traction in their fields. This factor is most salient in France, where the social, political, and scientific erasure of gay couples and their families has been a lasting feature of the French-but not U.S.—case. Indeed, U.S. experts enjoy both a comparatively more supportive academic environment and work in a country where gay families were legally recognized in some jurisdictions for decades. This made finding and studying them easier than in France. Indeed, academic barriers facing progressive French scholars are exacerbated by a social climate less sympathetic to gay parenting. 
Gay family invisibility in French media and political spheres, noted by other scholars (Garnier, 2012; Vecho \& Schneider, 2005), is both a symptom and cause of the illegitimacy of sexual minorities as research topics. French bans on surrogacy, adoption, and ART for same-sex couples have made it especially difficult for French gays and lesbians to have children in the first place. In addition, relative to the U.S., French public opinion has been historically more negative towards gay parenting. For example, from 2012 to 2014, support for same-sex adoption reached a high of $63 \%$ in the U.S. but sunk to $46 \%$ in France in May 2013 just before the legalization of marriage and adoption. ${ }^{4}$ Furthermore, counter to the U.S-where, as Gates and Rosenfeld described, scholars have constructed a picture of gay family demographics with the Census and other national surveys that either indirectly capture or explicitly ask about gay families-French interviewees said national research centers, like the Institut National d'Études Démographiques, have not historically gathered data allowing such measurement. Despite hoping they might eventually do so, some interviews argued administrators usually refuse to ask such questions, just as they do with race, because doing so would recognize a minority category and thus violate principles of French universalism. Complicating matters further, the UNAF, which is statutorily required to represent all French family associations, systematically refused to admit gay family organizations until the last few years, eliminating their voices from officially sanctioned discourse (Garnier, 2012; Robcis, 2013). In this climate, it has been especially difficult for French researchers to study the experiences of same-sex couples and their children.

Despite the ongoing and historical efforts of France's two gay family organizationsthe APGL and the ADFH - to encourage researchers to study their families (Gross, 2007), most French interviewees, including gays and lesbians, said gay families have long been

\footnotetext{
${ }^{4}$ Sources: Gallup, http://www.gallup.com/poll/170801/americans-say-sex-couples-entitledadopt.aspx?utm_source=marriage\&utm_medium=search\&utm_campaign=tiles; Copyright (C) 2015 Gallup, Inc. All rights reserved; Ifop, http://www.ifop.com/?option=com_publication\&type=poll\&id=2839; Copyright (C) 2015 Ifop, Inc. All rights reserved
} 
States. During the late 1990s, it was especially acute. Most interviewees working then, including those who conducted research with the APGL, such as Nadaud and Cadoret, said few people imagined gays and lesbians wanted or already had their own families. Both said gay parenting was "not a visible phenomenon." Gross, also a former president of the APGL, argued that gay parenting was largely underground. This relative erasure seems to have been true even as late as the last few years. For example, in the words of Erwann Binet, the lawmaker responsible for organizing the Assembée Générale's Judiciary Committee hearings in 2012, gay families have been, "totally abstract and inexistent in the minds of the French ... For them, homosexuals could not have children." This invisibility, and the lack of research it helps cause, serves French conservatives. Unlike in the United States, they can more easily minimize the phenomenon of gay families altogether and make claims that are difficult for progressive experts to counter without the data and social support to do so.

\section{Division among allied experts}

Finally, the degree of fragmentation among experts on the same ideological side also shapes their position in the field. In the U.S., despite some notable discord among progressive scholars over gay marriage, the struggle between gay rights supporters and opponents appears more salient. This progressive-conservative polarization characteristic of the U.S., and consistent with the national knowledge regimes literature (Campbell \& Pedersen, 2014), appears to limit weakening effects inter-left division have on progressive experts' current position in the field. In France, however, long-standing public division among left-leaning experts over gay family rights has made countering conservative dominance more difficult. Contrary to progressives, the data do not reveal any notable, public divisions among conservative experts over these issues in either country. Fragmentation thus appears to 
constitute a specific hurdle for progressive experts, especially in France.

American progressive experts described opposition stemming from concerns about perceived negative normative and political effects of their research, which sometimes limited their work. For instance, in the 1980s, psychologist Ilan Meyer encountered peer resistance in reviews and conferences when his research on "minority stress" cast doubt on accepted theory that gay and straight people had the same risk of psychiatric disorders. Some worried it could hurt gay people's image. He found, in fact, that "gay people [were] suffering [from] the impact of homophobia." Similarly, Peplau explained that prior to 1990s, psychologists hesitated comparing same-sex and different-sex couples to avoid, "imply[ing] heterosexuals were the standard." More radical scholars, such as critical theorist Michael Warner (1999) and sociologist Judith Stacey (Stacey \& Biblarz, 2001), criticized American gay family research for not fully embracing the queer potential of non-heteronormative parenting. Several interviewees, including Manning, Patterson, and law professor Nan Hunter, personally experienced or witnessed Stacey, who they all knew personally, suggest that most gay family scholarship reinforces heteronormativity by overemphasizing similarities between straight and gay families and their children's outcomes. Patterson in particular said Stacey criticized her and her colleagues' work in articles and conferences.

American conservative experts have unsuccessfully tried to exploit these academic divisions in courts. Attempting to cast doubt on the reliability of Patterson and others' research, they frequently cite Stacey in amicus briefs ${ }^{5}$ and in expert testimony in federal marriage trials. ${ }^{6}$ These strategies, nevertheless, appear to diminish the effects of intra-left fragmentation. For example, Stacey has responded by rejecting conservative manipulation of her work and emphasizing her support for her progressive colleagues. She lays some of this

\footnotetext{
${ }^{5}$ See for example: Brief of Robert P. George, Sherif Girgis, and Ryan T. Anderson as Amici Curiae in Support of Hollingsworth and Bipartisan Legal Advisory Board, Hollingsworth v. Perry and Windsor v. Bipartisan Legal Advisory Board, 570 U.S. 12-144 (2013).

${ }^{6}$ Perry v. Schwarzenneger 274 F. Supp. 4 (U.S. D.C. N. CA. 2010).
} 
out in a video denouncing anti-gay distortions of research ${ }^{7}$ and in interviews (Schilt, 2017). Furthermore, the way family sociologists reacted to the Regnerus affair-by rallying together through interpersonal networks and the ASA to critique his methods, findings, and conclusions via review boards, journal articles, amicus briefs, and expert testimonysuggests that partisanship can override progressive divisions.

The French field, in contrast, is characterized by historic and enduring conflict on the left caused by several famous, high-ranking, and politically connected experts—including anthropologists Françoise Héritier and Maurice Godelier, and sociologist Irène Théry—who changed their stances on same-sex marriage in the early 2000s. Before supporting it, they vehemently opposed same-sex marriage and parenting in the press and before parliament, denouncing their more progressive peers as radicals. With the exception of sociologist David Blankenhorn, few American academics have publically shifted this way.

The conflict originated at a time in the 1990s when these people, especially Théry, were family policy experts for the state and unofficially the Socialist Party. Sylviane Agacinski, a feminist philosopher and wife of then Socialist Primer Minister Lionel Jospin, who has never stopped fighting against gay families, echoed their views. Théry, though now a strong supporter of gay families, opposed the Pacs and same-sex marriage in the 1990s. “...We must continue to refuse homosexual marriage," she explained in an interview to $L e$ Monde, "because matrimony is the very institution of sex differences, linking together the couple and filiation through the presumption of paternity, which is the heart of marriage" (Aulagnon, 1997). She stressed the "finiteness of [homosexual] relationships" and wanted to limit all childrearing to heterosexual couples.

Many interviewees discussed the origin of the division and rivalry within the field around the time of the Pacs debates, before Théry and others changed their stances, and when

\footnotetext{
7 http://respectmyresearch.org/scientists/dr-judith-stacey/. Accessed 10/18/2015. See also http://www.prweb.com/releases/2006/07/prweb412920.htm. Accessed 06/25/2017.
} 
both sides were openly fighting with each other in the press as well as in public and academic conferences (Borrillo \& Fassin, 2001; Borrillo \& Lascoumes, 2002; Gross, 2007; Prearo, 2014; Robcis, 2013). In particular, they described a two-day conference in 1999 on gay couples and parenting, hosted by the APGL, as an especially striking example. At the conference, Théry, Fassin, and Borrillo confronted each other in a debate about whether supposed sex differences between men and women justify prohibiting same-sex couples from joint-adoption and full marriage rights or whether principles of equality trump such considerations (Peerbaye, 2000). The debate, which was "explosive" and dramatic according to several interviewees, led Fassin, Borrillo and their supporters, to leave the conference the next day and not publish in the proceedings. They were also simultaneously organizing their own conferences, one in 1998 and another 1999, which involved a critique of the role of experts, including Théry, in the Pacs debates. They also published several academic articles developing these arguments (Fassin, 1998, 2000a, 2000b) and an edited volume (Borrillo \& Fassin, 2001). At the same time, Théry was reiterating her critiques of them, for example, in an interview with the French intellectual journal Esprit (Abel, Coq, Garapon, \& Théry, 1998).

In the last decade, experts who had always supported gay family rights now find themselves on the same side as their former political and academic rivals. As a result of this conflict, progressive interviewees on both sides described episodes of career blockages, negative professional side effects, and defamation from their rivals. This clash-regardless of the veracity of each side's claims-limited progressives' capacity to resist conservative dominance in French knowledge production fields. First, in the 1990s, anti-gay marriage progressives provided intellectual coverage to conservative arguments. Second, according to every progressive French interviewee, the conflict leaves people feeling caught in an ongoing battle requiring one to take sides. This fragmentation continues to complicate work for 
progressive French knowledge producers in a small field where research is already underfunded, marginalized, and under attack by conservatives.

\section{Conclusion}

By testifying for and against gay families in the United States and France, academics and professionals provide expert capital—specific symbolic and material resources-to activists and decision-makers. Yet, as this article demonstrates, their capacity to produce, accumulate, and share that capital depends on how they overcome barriers and mobilize resources specific to their national knowledge production fields. Just as activists contend with political opportunity structures in the political field to accomplish their goals (Meyer, 2004; Swartz, 2013), experts I interviewed produced expertise in a contentious field where competition for resources and recognition is partisan and conditioned by nationally specific knowledge regimes. Circumstances in the United States and France relative to university and professional organizational structure, social and academic acceptance of gay families, and ideological division have all shaped how progressive and conservative experts have faired.

In the 2010s, American progressive experts had leveraged their way into a position of relative strength by pushing their universities and professional organizations to gradually acknowledge their work. They did so in a large field that presented more opportunities for better data collection than their French peers, who found themselves limited by a smaller, more hierarchical field where their institutions have been less receptive to their work, which already suffers from a chronic lack of social acceptance. Progressives in both countries also faced fragmentation within their ranks that hindered their work but which proved especially constraining in France. American conservative experts, though facing some marginalization from mainstream academics and official organizations, have mobilized networks that are stronger in a decentralized American system in order to counter progressive expert capital 
with varying degrees of success. Conservative French experts are also facing criticism for their views but, because they have historically held top academic and advisory board positions in the top-down French field, they have been able to maintain some dominance.

The current relative positions of experts in their fields, I argue, are the result of historical processes continent on the nationally specific circumstances described above. Their positions are likely to continue to change. For example, the relative strength of American progressive experts may only be temporary if conservative scholars and their allies successfully attack funding for research on gay families or sexual minorities more generally, as they have done in the past (Epstein, 2006). Recent right wing attacks (Schmidt, 2017) on progressive American academics and tepid university administrative responses in defending them could signal a shifting climate. In France, legalization of same-sex marriage and parenting as well as recent positive shifts in public opinion - the most recent poll finds a majority of French people support gay parenting - may help reduce the invisibility of gay families there. ${ }^{8}$ That could lead to more support for gay family research in the long run especially if conservative experts continue to lose ground on official advisory boards.

Explaining the degree of power experts of different ideological categories have in their fields and how they acquired it, which this article does, only captures one aspect of expert capital. It is equally important to analyze how experts interact with the people, such as activists and decision-makers, and institutions, such as courts and legislatures, that use their expertise.

First, research on social movements suggests that activists and experts interact through organizations, exchange ideas, learn from each other, and sometimes occupy both positions (Cresswell \& Spandler, 2013; Epstein, 1996; Holli, 2008). Building on my findings about the challenges experts within the academy and professional organizations face, the next

\footnotetext{
${ }^{8}$ Ifop, http://www.ifop.com/media/poll/3798-1-study_file.pdf; Copyright C 2017 Ifop, Inc. All rights reserved.
} 
analytical step could focus more specifically on the ways expert and social movement fields overlap and how national context conditions that intersection. For the U.S. case, this article points in the direction of people at think tanks and professional organizations, such as Clinton Anderson at the APA, who connect experts to each other and potentially with movement organizations. In France, the relationship between Martine Gross and gay family organizations as well as between Claire Neirinck and the UNAF are also a point of overlap between the two fields. In all cases, my research suggests that the relatively autonomous knowledge production field poses specific constraints that will likely shape interactions between experts and activists.

Second, my findings point to the fact that strong progressive expert capital grounded in the scientific consensus on childhood outcomes was especially useful for pro-gay marriage advocates in the context of U.S. courts. I argue here that circumstances in the American knowledge production field helped progressive experts create that consensus. Going forward, research should explore how courts, as opposed to, say, legislatures may be a more effective venue for this kind of expert capital. This would help explain why American gay rights advocates, who can take advantage of powerful scientific expertise on sexual minorities and their families, seek success through litigation (Mezey, 2007). In addition, feedback loops between policy outlets and knowledge producers (Jasanoff, 2004) may also have an impact on expert capital. For example, the strong demand for peer-reviewed social science created by American courts and the high bar they put on standards of evidence (Ramsey \& Kelly, 2004) has led both progressive and conservative experts and their allies to produce research. The Regnerus affair is a good example of this process. To counter the scientific consensus, the Witherspoon institute funded the data collection for Regnerus's article, which appears to have been motivated precisely for use in courts.

This comparison between the U.S. and France highlights factors impacting experts' 
power to produce knowledge in their countries. These results have implications for making sense of how they do so in other countries. In order to understand why conservative and progressive experts gain and lose power in other places, scholarship might examine the knowledge regimes, institutional embrace of research on minorities, organizational power, gay family visibility, and ideological fragmentation there. Other national cases would also show which of these factors is perhaps idiosyncratic to the U.S. and France and reveal novel ones. This study also has implications for different issues. Extending this comparison to other highly politicized debates involving expertise, such as climate change or autism, may also bring to light common dynamics all experts navigate as they produce knowledge for decision-makers.

\section{Works Cited}

Abel, O., Coq, G., Garapon, A., \& Théry, I. (1998). Les Occassions manquées du PACS (entretien). Esprit, 201-214.

Adams, J., \& Light, R. (2015). Scientific Consensus, the Law, and Same Sex Parenting Outcomes. Social Science Research, 53, 300-310.

AFP. (2013, March 15). Mariage pour tous : 170 juristes contre le "marché des enfants." Le Monde.fr.

Allen, D. W., Pakaluk, C., \& Price, J. (2013). Nontraditional Families and Childhood Progress Through School: A Comment on Rosenfeld. Demography, 50(30), 955-961. American Psychological Association. (2005). Lesbian and Gay Parenting. Washington, DC: American Psychological Association.

Armstrong, E. A., \& Bernstein, M. (2008). Culture, Power, and Institutions: A MultiInstitutional Politics Approach to Social Movements. Sociological Theory, 26(1), 74 99. 
Aulagnon, M. (1997, November 25). La fausse bonne idée du contrat d'union sociale, c'est de tout mélanger. Le Monde.

Badgett, M. V. L. (2009). When gay people get married: what happens when societies legalize same-sex marriage. New York: NYU Press.

Becker, J. (2015). Forcing the Spring: Inside the Fight for Marriage Equality. New York: Penguin Books.

Béland, D., \& Cox, R. H. (Eds.). (2010). Ideas and Politics in Social Science Research. Oxford, UK: Oxford University Press.

Bérard, Y., \& Crespin, R. (Eds.). (2010). Aux Frontières de l'expertise : Dialogues Entre Savoirs et Pouvoirs. Rennes, France: Presses Universitaires de Rennes.

Bernstein, M., \& Naples, N. A. (2015). Altared States: Legal Structuring and Relationship Recognition in the U.S., Canada, and Australia. American Sociological Review, 80(6), $1226-1249$.

Boltanski, L., \& Thévenot, L. (1991). De la justification: les économies de la grandeur. Paris: Gallimard.

Borrillo, D., \& Fassin, É. (Eds.). (2001). Au delà du pacs : L'Expertise Familiale à l'épreuve de l'homosexualité. Paris: Presses Universitaires de France.

Borrillo, D., \& Lascoumes, P. (2002). Amours égales? Le PaCS, les homosexuels et la gauche. Paris: La Découverte.

Bottoms, B. L., Kovera, M. B., \& McAuliff, B. D. (2002). Children, Social Science, and the Law. Cambridge, UK: Cambridge University Press.

Bourdieu, P. (1975). The specificity of the scientific field and the social conditions of the progress of reason. Social Science Information, 14(6), 19-47.

Bourdieu, P. (1986). The Forms of Capital. In R. J. (Ed.), Handbook of Theory and Research for the Sociology of Education (pp. 46-58). New York: Greenwood Press. 
Brint, S. (1996). In an Age of Experts. Princeton, NJ: Princeton University Press.

Brubaker, R. (1992). Citizenship and nationhood in France and Germany. Cambridge, MA:

Harvard University Press.

Campbell, J. L., \& Pedersen, O. K. (2014). The National Origins of Policy Ideas: Knowledge Regimes in the United States, France, Germany, and Denmark. Princeton University Press.

Cardiff, C. F., \& Klein, D. B. (2005). Faculty partisan affiliations in all disciplines: A voterregistration study. Critical Review, 17(3-4), 237-255.

Cimmings, S. L., \& NeJaime, D. (2009). Lawyering for Marriage Equality. UCLA Law Review, 57, 1235-1331.

Commaille, J. (2006). La famille, l'état, le politique : une nouvelle économie des valeurs. Informations sociales, 136(8), 100-111.

Cresswell, M., \& Spandler, H. (2013). The Engaged Academic: Academic Intellectuals and the Psychiatric Survivor Movement. Social Movement Studies, 12(2), 138-154.

Daumas, C. (2016, December 14). Valérie Pécresse coupe les bourses au genre. Libération.fr. Dilling, L., \& Lemos, M. C. (2011). Creating usable science: Opportunities and constraints for climate knowledge use and their implications for science policy. Global Environmental Change, 21(2), 680-689.

Doherty, B., \& Hayes, G. (2014). Having your day in court: judicial opportunity and tactical choice in anti-GMO campaigns in France and the United Kingdom. Comparative Political Studies, 47(1), 3-29.

Dunlap, R. E., \& Jacques, P. J. (2013). Climate Change Denial Books and Conservative Think Tanks: Exploring the Connection. American Behavioral Scientist, 57(6), 699731.

Eliacheff, C. (2001). Malaise dans la psychanalyse. Esprit, 273, 62-77. 
Epstein, S. (1996). Impure Science: AIDS, Activism, and the Politics of Knowledge. Berkeley: University of California Press.

Epstein, S. (2006). The New Attack on Sexuality Research: Morality and the Politics of Knowledge Production. Sexuality Research and Social Policy, 3(1), 1-12.

Eyal, G., \& Buchholz, L. (2010). From the Sociology of Intellectuals to the Sociology of Interventions. Annual Review of Sociology, 36(1), 117-137.

Fassin, É. (1998). Le savant, l'expert et le politique: la famille des sociologues. Genèses, $32(1), 156-169$.

Fassin, É. (2000a). L’intellectuel spécifique et le PaCS : politiques des savoirs. Mouvements, (7), 68-76.

Fassin, É. (2000b). Usages de la science et science des usages. L'Homme. Revue française d'anthropologie, (154-155), 391-408.

Ferree, M. M. (2003). Resonance and Radicalism: Feminist Framing in the Abortion Debates of the United States and Germany. The American Journal of Sociology, 109(2), 304344.

Fetner, T. (2008). How the Religious Right Shaped Lesbian and Gay Activism. Minneapolis, MN: University of Minnesota Press.

Fischer, F. (2000). Citizens, Experts, and the Environment: The Politics of Local Knowledge. Durham, NC: Duke University Press.

Fligstein, N., \& McAdam, D. (2012). A Theory of Fields. Oxford, UK: Oxford University Press.

Fourcade, M. (2009). Economists and Societies: Discipline and Profession in the United States, Britain, and France, 1890s to 1990s. Princeton, NJ: Princeton University Press. 
Garnier, É. (2012). L’homoparentalité en France: La bataille des nouvelles familles. Paris:

Thierry Marchaisse Editions.

Gregorio, M. D. (2014). Gaining Access to the State: Political Opportunities and Agency in Forest Activism in Indonesia. Social Movement Studies, 13(3), 381-398.

Gross, M. (2007). Quand et comment l'homoparentalité est-elle devenue un objet «légitime» de recherche en sciences humaines et sociales? Socio-logos, (2).

Gunn, T. J. (2004). Religious Freedom and Laicite: A Comparison of the United States and France. Brigham Young University Law Review, 2004, 419-506.

Holli, A. M. (2008). Feminist Triangles: A Conceptual Analysis. Representation, 44(2), 169185.

Hull, K. E. (2006). Same-Sex Marriage: The Cultural Politics of Love and Law. Cambridge, UK: Cambridge University Press.

Jasanoff, S. (Ed.). (2004). States of Knowledge: The Co-Production of Science and the Social Order. New York: Routledge.

King, B. G., \& Walker, E. T. (2014). Winning hearts and minds: Field theory and the three dimensions of strategy. Strategic Organization, 12(2), 134-141.

Klein, D. B., \& Stern, C. (2005). Professors and their politics: The policy views of social scientists. Critical Review, 17(3-4), 257-303.

Knorr-Cetina, K. (1999). Epistemic Cultures: How the Sciences Make Knowledge. Cambridge, MA: Harvard University Press.

Kuhar, R. (2015). Playing with science: Sexual citizenship and the Roman Catholic Church counter-narratives in Slovenia and Croatia. Women's Studies International Forum, 49, 84-92.

Lamont, M. (2002). The Dignity of Working Men: Morality and the Boundaries of Race, Class, and Immigration. Cambridge, MA: Harvard University Press. 
Lamont, M., \& Thévenot, L. (Eds.). (2000). Rethinking Comparative Cultural Sociology: Repertoires of Evaluation in France and the United States. Cambridge: Cambridge University Press.

Maher, M. J., Landini, K., Emano, D. M., Knight, A. M., Lantz, G. D., Parrie, M., ... Sever, L. M. (2009). Hirschfeld to Hooker to Herek to High Schools: A Study of the History and Development of GLBT Empirical Research, Institutional Policies, and the Relationship Between the Two. Journal of Homosexuality, 56(7), 921-958.

Manning, W. D., Fettro, M. N., \& Lamidi, E. (2014). Child Well-Being in Same-Sex Parent Families: Review of Research Prepared for American Sociological Association Amicus Brief. Population Research and Policy Review, 33(4), 485-502.

McCaffrey, E. (2005). The Gay Republic: Sexuality, Citizenship and Subversion in France. Aldershot, UK: Ashgate.

Medvetz, T. (2012). Think Tanks in America. Chicago, IL: University Of Chicago Press.

Meyer, D. S. (2004). Protest and political opportunities. Annual Review of Sociology, 30, $125-145$.

Mezey, S. G. (2007). Queers in Court: Gay Rights Law and Public Policy. Rowman \& Littlefield Publishers.

Mezey, S. G. (2009). Gay Families and the Courts: The Quest for Equal Rights. Lanham, MD: Rowman \& Littlefield Publishers.

Millard, E., Brunet, P., Hennette-Vauchez, S., \& Champeil-Desplats, V. (2013, March 20). Marigae pour tous : juristes, taisons-nous!

Moore, M. R., \& Stambolis-Ruhstorfer, M. (2013). LGBT Sexuality and Families at the Start of the Twenty-First Century. Annual Review of Sociology, 39(1), 491-507.

Mucciaroni, G. (2008). Same Sex, Different Politics: Success and Failure in the Struggles Over Gay Rights. Chicago: University of Chicago Press. 
Murphy, P. J., Kickul, J., Barbosa, S. D., \& Titus, L. (2007). Expert Capital and Perceived

Legitimacy. The International Journal of Entrepreneurship and Innovation, 8(2), $127-138$.

Paternotte, D. (2011). Revendiquer le “mariage gay”: Belgique, France, Espagne. Bruxelles: Editions de l'Université de Bruxelles.

Patterson, C. J. (1992). Children of Lesbian and Gay Parents. Child Development, 63(5), $1025-1042$.

Peerbaye, A. (2000, September). L'Invention de l'homoparentalité: Acteurs, arènes et rhétoriques autour de la question de la filiation homosexuelle (Master's Thesis (DEA)). ENS, Cachan, France.

Perreau, B. (2016). Queer Theory: The French Response. Palo Alto, CA: Stanford University Press.

Prearo, M. (2014). Le Moment Politique de l'Homosexualité: Mouvements, Identités, et Communautés en France. Lyon, France: Presses Universitaires de Lyon.

Ramsey, S. H., \& Kelly, R. F. (2004). Social Science Knowledge in Family Law Cases: Judicial Gate-Keeping in the Daubert Era. University of Miami Law Review, 59, 1.

Regnerus, M. (2012). How different are the adult children of parents who have same-sex relationships? Findings from the New Family Structures Study. Social Science Research, 41(4), $752-770$.

Richman, K. D. (2009). Courting Change: Queer Parents, Judges, and the Transformation of American Family Law. New York: New York University Press.

Robcis, C. (2013). The Law of Kinship: Anthropology, Psychoanalysis, and the Family in France. Ithaca, NY: Cornell University Press.

Rosenfeld, M. (2013). Reply to Allen et al. Demography, 50(3), 963-969. 
Rosenfeld, M. J. (2010). Nontraditional families and childhood progress through school. Demography, 47(3), 755-775.

Schilt, P. (2017, March 25). Sociologist Judith Stacey: Get Rid of Marital Privilege.

Schmidt, P. (2017, June 22). Professors' Growing Risk: Harassment for Things They Never Really Said. The Chronicle of Higher Education.

Simon, P. (2008). The Choice of Ignorance The Debate on Ethnic and Racial Statistics in France. French Politics, Culture \& Society, 26(1), 7-31.

Singly, F. de. (2007). Sociologie de la famille contemporaine (3e édition). Paris: Armand Colin.

Smith, M. (2008). Political Institutions and Lesbian and Gay Rights in the United States and Canada. New York: Taylor \& Francis.

Stacey, J., \& Biblarz, T. J. (2001). (How) Does the Sexual Orientation of Parents Matter? American Sociological Review, 66(2), 159-183.

Stambolis-Ruhstorfer, M. (2015). The Culture of Knowledge: Constructing “Expertise” in Legal Debates on Marriage and Kinship for Same-Sex Couples in France and the United States (PhD Dissertation). University of California Los Angeles and Ecole des Hautes Etudes en Sciences Sociales, Los Angeles, CA.

Swartz, D. L. (2013). Symbolic Power, Politics, and Intellectuals: The Political Sociology of Pierre Bourdieu. Chicago: University of Chicago Press.

Tarrow, S. (2010). The strategy of paired comparison: Toward a theory of practice. Comparative Political Studies, 43(2), 230-259.

UNAF. (2012). Les questions du mariage, de la filiation et de l'autorité parentale pour les couples de même sexe. Union Nationale des Associations Familiales.

Vecho, O., \& Schneider, B. (2005). Homoparentalité et développement de l'enfant : bilan de trente ans de publications. La psychiatrie de l'enfant, Vol. 48(1), 271-328. 
THIS IS A PRE-PRODUCTION AUTHOR'S COPY

Link to published article: https://www.tandfonline.com/doi/full/10.1080/14742837.2018.1482206 Contact author for article

Vecho, O., \& Schneider, B. (2015). Attitudes toward gay and lesbian parents: A comparison among French and Quebec psychologists. Canadian Journal of Behavioural Science, $47(1), 102-112$.

Warner, M. (1999). Normal and Normaller: Beyond Gay Marriage. GLQ, 5(2), 119-172.

Yoshino, K. (2015). Speak Now: Marriage Equality on Trial. New York: Broadway Books. 